\title{
Epidemiological study of traumatic dental injuries in 5- to 6-year-old Brazilian children
}

\section{Gabriela Oliveira BERTI(a) Daniela HESSE(a) \\ Clarissa Calil BONIFÁCIO(b) Daniela Prócida RAGGIO(a) Marcelo José Strazzeri BÖNECKER ${ }^{(a)}$}

(a) Universidade de São Paulo - USP, School of Dentistry, Orthodontics and Pediatric Dentistry Department, São Paulo, SP, Brazil.

(b)Academic Centre for Dentistry Amsterdam - ACTA, Department of Conservative Dentistry, Amsterdam, The Netherlands.

Declaration of Interests: The authors certify that they have no commercial or associative interest that represents a conflict of interest in connection with the manuscript.

Corresponding Author:

Gabriela Oliveira Berti

E-mail: gabriela.berti@usp.br

DOI: 10.1590/1807-3107BOR-2015.vol29.0103

Submitted: Sep 25, 2014

Accepted for publication: May 15, 2015

Last revision: Jul 07, 2015

\begin{abstract}
Monitoring traumatic dental injury (TDI) in primary teeth through epidemiological cross-sectional surveys provides descriptive information relevant to the development of public policies focused on the prevention of such injuries for the target population. The aim of this study was to assess the prevalence of TDI in 5- to 6-year-old Brazilian children and its association with biological and socioeconomic factors. A total of 684 children aged 5 to 6 years old, from 11 public schools in the city of Barueri (Brazil) were evaluated. Clinical examinations were carried out in the schools, by two trained and calibrated examiners. Gauze and a mouth mirror were used for the examinations. The reported TDIs were classified according to the Andreasen (2007) criteria for primary teeth. The results showed that $52.3 \%$ of the children had TDI. Enamel fracture (63.4\%) was the most frequently observed sign of TDI, and the most affected teeth were the primary maxillary central incisors (26.9\% maxillary right central incisor and 24\% maxillary left central incisor). There was no association between the presence of TDI and biological or socioeconomic factors. In conclusion, the prevalence of TDI was high and had no statistically significant association with biological and socioeconomic factors.
\end{abstract}

Keywords: Tooth Injuries; Epidemiology; Tooth, Deciduous; Pediatric Dentistry.

\section{Introduction}

Traumatic dental injury (TDI) is a common disorder in children. It is caused by an external impact on the mineralized and supporting tooth tissues. The severity varies according to the extent of the injury, which can involve enamel, dentin, pulp, alveolar processes and the periodontal ligament. In addition, TDI may cause pain and emotional harm to the child, due to its esthetic and functional implications. ${ }^{1,2}$

According to some epidemiological studies, the prevalence of dental caries in schoolchildren has decreased in recent years, ${ }^{3}$ and is no longer as high as it was during several decades. ${ }^{4}$ On the other hand, a recent study indicated a trend of growing prevalence of TDI among Brazilian preschool children. ${ }^{5}$

Even though it is known that TDI affects children worldwide, ${ }^{6}$ there are only two epidemiological studies involving 5- to 6-year-old children reported in the dental literature,, 8 and they provide important guidelines 
to help develop public policies focused on preventing TDI in the target population., ${ }^{7,8}$

Whenever the prevalence of trauma is studied, researchers try to investigate its association with biological and socioeconomic factors. In relation to the biological factors, an association was reported between TDI and age. ${ }^{8}$ Regarding the socioeconomic factors, a few epidemiological studies on TDI in the primary dentition described no significant association between trauma and socioeconomic factors. ${ }^{9,10}$ However, other studies found that there was a greater prevalence of TDI in higher socioeconomic classes. ${ }^{11,12}$

Epidemiological studies of TDI, in general, describe the prevalence, severity and risk factors. According to the dental literature there are very few studies on TDI prevalence in 5- to 6-year-old children worldwide; therefore, the aim of this epidemiological study was to assess this information in a Brazilian sample, and verify its association with biological and socioeconomic factors. This information could be very useful in devising preventive guidelines for pediatric patients, and establishing public policies for the target child population.

\section{Methodology}

This epidemiological survey was carried out after approval by the Research Ethics Committee of the School of Dentistry, Universidade de São Paulo - USP, Brazil (approval protocol: 190/08).

\section{Study population and data collection}

A cross-sectional study was performed on a population-based sample of 5- to 6-year-old schoolchildren living in Barueri, São Paulo, Brazil. At the time, Barueri had an estimated population of 240,656 inhabitants that included 18,600 children younger than 9 years old..$^{13}$

The 11 schools where the clinical examinations were carried out in Barueri were selected randomly in both rural and urban areas, to enable representation for the entire city. All of the 5- to 6-year-old children enrolled in these schools were invited to participate in the study.

The sample size was determined using the formulas to calculate the precision of a single proportion, according to Kirkwood. ${ }^{14}$ It was estimated that a minimum sample size of 625 children was required to achieve a level of precision with a standard error of $<2 \%$ and a $95 \%$ confidence interval. Even so, the minimal sample size required was 625 children. We decided to invite all the children 5 to 6 years old, enrolled in the 11 selected schools (770 children), since it was not possible to estimate how many would agree. A total of 684 children aged 5 to 6 years old, of both genders, agreed to participate (positive response rate of $88.8 \%$ ). The written consent to participate in the survey was obtained by the children's legal guardian. The total sample size comprised 363 boys (154: 5 years old and 209: 6 years old) and 321 girls (166: 5 years old and 155: 6 years old).

Only 5- to 6-year-old children with all their deciduous teeth were examined. An exclusion criterion was children with permanent teeth or with missing deciduous teeth. Two examiners underwent two sessions of training and calibration exercises for an $8 \mathrm{~h}$ period with pictures of clinical cases for different TDI conditions, with an interval of 1 week between sessions, to obtain intra- and interexaminer reliability kappa values. Regarding the calibration process, the examiners obtained an interexaminer reliability value of 0.89 , according to Cohen's kappa coefficient, and an intraexaminer agreement of 0.90 .

Visual inspection for TDI was performed at the schools with a headlight, dental mirror and gauze. The children remained seated on school chairs during the examination, and two previously calibrated examiners performed the data collection.

The criteria used to assess TDI were based on Andreassen' classification, ${ }^{15}$ and only anterior primary teeth were considered in this investigation. The socioeconomic indicators were obtained according to part of the index recommended by Jarman, ${ }^{16}$ which included information from the child, mother and father. The variables selected from the Jarman index for this study were family structure, mother's education, father's education, family income, household overcrowding, home ownership and number of children.

\section{Statistical Analysis}

Data analyses were performed using STATA software 11.2 (Stata Corp., College Station, USA). 
Poisson Regression analysis with robust variance was performed to associate the child's characteristics and sociodemographic conditions with TDI. Univariate Poisson Regression analysis was performed to select variables with a p-value $\leq 0.20$ to use in the model. The prevalence ratios (PR) and 95\% confidence intervals ( $95 \% \mathrm{CI})$ were calculated, and the level of significance was set at $5 \%$.

\section{Results}

A total of 303 children (52.3\%) presented signs of TDI. The prevalence of TDI was 52.7\% in 5-year-old children, and $52.1 \%$ in 6 -year-olds. Table 1 shows the distribution of children with trauma according to gender and age. The most common TDI found was enamel fractures, followed by cracks in the enamel (Table 1).

Regarding the distribution of TDI, the maxillary central incisors were found to be the most affected teeth, with no difference between sides: maxillary right central incisor (26.9\%) and maxillary left central incisor (24\%), followed by maxillary right lateral incisors (26.3\%) and maxillary left lateral incisors (22.8\%).

The results of Poisson's analysis are described in Table 2. They show that there was no statistically significant association between TDI and biological (age and gender) or socioeconomic factors ( $p>0.05)$.

\section{Discussion}

In the present study, the TDI prevalence in 5 - to 6 -year-old children was $52.3 \%$. This could be considered high, if compared with the only other two Brazilian studies. ${ }^{78}$ Robson et al. ${ }^{7}$ showed a prevalence of $39.1 \%$ in a population of 0 - to 5 -year-old children, and Viegas et al. ${ }^{8}$ found a prevalence of $62.1 \%$ in a population of 5-year-old preschool children; both authors concluded that these prevalence rates were high. The prevalence of TDI increases with age, owing to its cumulative effect. We believe that the higher prevalence of TDI in the present study, as well as the prevalence rate found by Viegas et al., ${ }^{8}$ can be attributed to the older age of the children, in comparison with the age of the children in the Robson et al. ${ }^{7}$ study sample.

The discrepancy in the prevalence rate could be attributed to the different epidemiological methodology used by these authors to collect TDI data. In fact the lack of a standardized methodology to deal with TDI epidemiological data has led to studies with discrepant values in all the age groups. ${ }^{2}$

We found that the teeth most affected by TDI were the upper incisors, corroborating other studies in the literature; this is probably due to their anatomical position in the oral cavity. ${ }^{17,18}$

Similar to the findings of other authors, ${ }^{1,19}$ the most prevalent type of TDI was enamel fracture, followed by enamel crack. Regarding enamel fractures, these do not present a severe aesthetic and functional impairment, compared with other signs of TDI.,15,19 Regarding cracks in the enamel, as a rule, they do not require treatment. However, in the case of multiple cracks, it is advisable to seal the enamel surface with a flowable composite, to prevent staining from food or beverages. ${ }^{15}$ As for the treatment of restricted enamel fractures, sharp enamel edges can be smoothed to prevent laceration of the tongue or lips. Moreover, the prognosis of cracks and fractures in enamel is very good, and the risk of pulp necrosis is extremely low;

Table 1. Absolute and percentage distribution of children affected by type of coronary tissue trauma in primary teeth according to age and gender.

\begin{tabular}{|c|c|c|c|c|c|c|c|c|c|c|}
\hline \multirow{3}{*}{$\begin{array}{l}\text { TDls } \\
\text { (mineralized tissue) }\end{array}$} & \multicolumn{4}{|c|}{5 -year-olds } & \multicolumn{4}{|c|}{ 6-year-olds } & \multirow{2}{*}{\multicolumn{2}{|c|}{ Total }} \\
\hline & \multicolumn{2}{|c|}{ M } & \multicolumn{2}{|c|}{$\mathrm{F}$} & \multicolumn{2}{|c|}{ M } & \multicolumn{2}{|c|}{$\mathrm{F}$} & & \\
\hline & $\mathrm{N}$ & $\%$ & $\mathrm{~N}$ & $\%$ & $\mathrm{~N}$ & $\%$ & $\mathrm{~N}$ & $\%$ & $\mathrm{~N}$ & $\%$ \\
\hline Enamel crack & 11 & 16.4 & 14 & 23 & 17 & 18.5 & 27 & 32.6 & 69 & 22.8 \\
\hline Enamel & 46 & 68.7 & 42 & 69 & 58 & 63.1 & 46 & 55.4 & 192 & 63.4 \\
\hline Enamel-dentine & 8 & 12 & 5 & 8.2 & 16 & 17.4 & 8 & 9.7 & 37 & 12.2 \\
\hline Enamel-dentine-pulp & 2 & 3 & 0 & 0 & 1 & 1.1 & 2 & 2.5 & 5 & 1.7 \\
\hline Total & 67 & 100 & 61 & 100 & 92 & 100 & 83 & 100 & 303 & 100 \\
\hline
\end{tabular}


Table 2. Univariate and Multivariate Poisson Regression analysis of child-related and socioeconomic factors associated with dental trauma.

\begin{tabular}{|c|c|c|c|c|}
\hline Independent Variables & Crude PR 95\%Cl & p & Adjusted PR 95\%Cl & $p$ \\
\hline \multicolumn{5}{|l|}{ Level 1: Child characteristic variables } \\
\hline \multicolumn{5}{|l|}{ Gender (ref.: Female) } \\
\hline \multirow[t]{2}{*}{ Male } & 1.16 & 0.297 & - & - \\
\hline & $0.87-1.54$ & & & \\
\hline \multicolumn{5}{|l|}{ Age (ref.: 5 years) } \\
\hline \multirow[t]{2}{*}{6 years } & 0.54 & 0.000 & 0.71 & 0.130 \\
\hline & $0.40-0.74$ & & $0.46-1.10$ & \\
\hline \multicolumn{5}{|l|}{ Level 2: Socioeconomic variables } \\
\hline \multicolumn{5}{|l|}{ Family structure (ref.: Both parents) } \\
\hline \multirow[t]{2}{*}{ Reconstituted Family } & 0.54 & 0.031 & 0.52 & 0.183 \\
\hline & $0.31-0.94$ & & $0.20-1.35$ & \\
\hline \multirow[t]{2}{*}{ Parent } & 1.08 & 0.672 & 1.07 & 0.869 \\
\hline & $0.74-1.58$ & & $0.46-2.50$ & \\
\hline \multicolumn{5}{|c|}{ Mother's education (ref.: After middle school) } \\
\hline \multirow[t]{2}{*}{ Up to middle school } & 1.32 & 0.228 & - & - \\
\hline & $0.83-2.07$ & & & \\
\hline \multicolumn{5}{|c|}{ Father's education (ref.: After middle school) } \\
\hline \multirow[t]{2}{*}{ Up to middle school } & 1.12 & 0.621 & - & - \\
\hline & $0.69-1.83$ & & & \\
\hline \multicolumn{5}{|l|}{ Family income (ref.: No income) } \\
\hline \multirow[t]{2}{*}{ Up to 2 Brazilian minimum wages } & 0.60 & 0.127 & 0.57 & 0.097 \\
\hline & $0.31-1.15$ & & $0.30-1.10$ & \\
\hline \multirow[t]{2}{*}{$>2$ Brazilian minimum wages } & 0.75 & 0.420 & 0.74 & 0.384 \\
\hline & $0.38-1.48$ & & $0.37-1.45$ & \\
\hline \multicolumn{5}{|c|}{ Household overcrowding (ref.: Up to 1 person per room) } \\
\hline \multirow[t]{2}{*}{$>1$ person per room } & 0.88 & 0.481 & - & - \\
\hline & $0.63-1.24$ & & & \\
\hline \multicolumn{5}{|l|}{ Home ownership (ref.: Owned house) } \\
\hline \multirow[t]{2}{*}{ Rented house } & 0.98 & 0.904 & - & - \\
\hline & $0.72-1.32$ & & & \\
\hline \multicolumn{5}{|l|}{ Number of children (ref.: 1) } \\
\hline \multirow[t]{2}{*}{2} & 1.02 & 0.889 & - & - \\
\hline & $0.71-1.47$ & & & \\
\hline \multirow[t]{2}{*}{$\geq 3$} & 1.03 & 0.865 & - & - \\
\hline & $0.70-1.50$ & & & \\
\hline
\end{tabular}

PR: Prevalence ratio; $\mathrm{Cl}$ : Confidence interval; $\mathrm{p}^{*}$ : $\mathrm{p}$-value of the final model.

furthermore, the potential expenses for treatment of these TDI types are minimal. ${ }^{15}$

The severity of trauma must be determined by a dentist and preferably the same dentist should follow up the traumatized tooth until the permanent successor erupts, when the trauma occurs in the primary dentition. ${ }^{15}$ Even minor traumas may cause serious repercussions with damage to the permanent successor, thus pointing out the need to seek treatment for a traumatized primary tooth. Ideally, these treatments should be performed in public health centers, because as reported in this research, the prevalence of TDI in schoolchildren from public schools is high.

Some studies showed that the prevalence of TDI is higher in boys than in girls, ${ }^{20,21}$ however many others have not found a difference between genders, just as we also found none. $5,9,10,22$ 
Viegas et al. ${ }^{8}$ conducted a study in 5-year-old children in order to investigate the presence of trauma associated with socioeconomic variables, and found no significant association, corroborating the findings of our study. The absence of an association between TDI and socioeconomic factors may be explained by the homogenous nature of the study sample, since all the children came from public schools. ${ }^{9,10}$

Since this was a cross-sectional study, there were some limitations to the methodology. Only visual inspection for TDI was performed, and the children were examined in school chairs. Consequently, the lack of radiographs precluded the diagnosis of some types of fractures.

On the other hand, a well designed cross-sectional study allows the inclusion of a large population-based epidemiological sample representative of a city like Barueri (Brazil), and this representative sample allows extrapolating the findings to the general population. Other epidemiological studies are needed to determine

\section{References}

1. Ferreira JMS, Andrade EMF, Katz CRT, Rosenblatt A. Prevalence of dental trauma in deciduous teeth of Brazilian children. Dent Traumatol. 2009 Apr;25(2):219-23. doi: 10.1111/j.1600-9657.2008.00754.x.

2. Aldrigui JM, Abanto J, Carvalho TS, Mendes FM, Wanderley MT, Bönecker $M$, et al. Impact of traumatic dental injuries and malocclusions on quality of life of young children. Health Qual Life Outcomes. 2011 Sep 24;9:78. doi: 10.1186/1477-7525-9-78.

3. Bönecker M, Ardenghi TM, Oliveira LB, Sheiham A, Marcenes W. Trends in dental caries in 1- to 4-year-old children in a Brazilian city between 1997 and 2008. Int J Paediatr Dent. 2010 Mar;20(2):125-31. doi:10.1111/j.1365-263X.2009.01030.x.

4. Oliveira LB, Sheiham A, Bönecker M. Exploring the association of dental caries with social factors and nutritional status in Brazilian preschool children. Eur J Oral Sci. 2008 Feb;116(1):37-43. doi: 10.1111/j.1600-0722.2007.00507.x.

5. Bonini GAVC, Marcenes W, Oliveira LB, Sheiham A, Bönecker M. Trends in the prevalence of traumatic dental injuries in Brazilian preschool children. Dent Traumatol. 2009 Dec;25(6):594-8. doi: 10.1111/j.1600-9657.2009.00826.x. Epub 2009 Sep 24.

6. Norton E, O'Connell AC. Traumatic dental injuries and their association with malocclusion in the primary dentition of Irish children. Dent Traumatol. 2012 Feb;28(1):81-6. doi: 10.1111/j.1600-9657.2011.01032.x. Epub 2011 Jul 27. the prevalence of TDI and associated factors in 5- to 6-year-old children, because there are few studies in the literature.

\section{Conclusion}

The prevalence of TDI was high and not associated with biological and/or socioeconomic factors. The study showed that the TDI fractures had not been treated in the study children, and highlighted the importance of implementing health promotion strategies for preventing TDI in the child population.

\section{Acknowledgments}

This study had the collaboration of several participants, including graduates from the FOUSP (Faculdade de Odontologia, Universidade de São Paulo) Pediatric Dentistry Seminar, the city of Barueri - SP, and the Academic Centre for Dentistry Amsterdam (ACTA), Amsterdam, The Netherlands.

7. Robson F, Ramos-Jorge ML, Bendo CB, Vale MP, Paiva SM, Pordeus IA. Prevalence and determining factors of traumatic injuries to primary teeth in preschool children. Dent Traumatol. 2009 Feb;25(1):118-22. doi: 10.1111/j.1600-9657.2008.00725.x.

8. Viegas CM, Scarpelli AC, Carvalho AC, Ferreira FM, Pordeus IA, Paiva SM. Predisposing factors for traumatic dental injuries in Brazilian preschool children. Eur J Paediatr Dent. 2010 Jun;11(2):59-65.

9. Zadik D. A survey of traumatized primary anterior teeth in Jerusalem preschool children. Community Dent Oral Epidemiol. 1976 Jul;4(4):149-51.

10. Oliveira LB, Marcenes W, Ardenghi TM, Sheiham A, Bönecker M. Traumatic dental injuries and associated factors among Brazilian preschool children. Dent Traumatol. 2007 Apr;23(2):76-81.

11. Granville-Garcia AF, Menezes VA, Lira PI. Dental trauma and associated factors in Brazilian preschoolers. Dent Traumatol. 2006 Dec;22(6):318-22.

12. Feldens CA, Kramer PF, Vidal SG, Faraco-Junior IM, Vítolo MR. Traumatic dental injuries in the first year of life and associated factors in Brazilian infants. J Dent Child (Chic). 2008 Jan-Apr;75(1):7-13.

13. Instituto Brasileiro de Geografia e Estatística [homepage]. Brasília (DF): Instituto Brasileiro de Geografia e Estatística; 2010 [cited 2013 Nov 27]. Available from: http://www.ibge. gov.br/home/default.php. 
14. Kirkwood BR. Essentials of medical statistics. Oxford: Blackwell Scientific Publications; 1988. 171 p.

15. Andreasen JO, Andreasen FM, Andersson L. Textbook and color atlas of traumatic injuries to the teeth. 4th ed. Copenhagen: Munskgaard; 2007. 912 p.

16. Jarman B. Identification of under privileged areas. $\mathrm{Br}$ Med J (Clin Res Ed). 1983 May 28;286(6379):1705-9.

17. Baghdady VS, Ghose LJ, Enke H. Traumatized anterior teeth in Iraqi and Sudanese children--a comparative study. J Dent Res. 1981 Mar;60(3):677-80.

18. Schuch HS, Goettems ML, Correa MB, Torriani DD, Demarco FF. Prevalence and treatment demand after traumatic dental injury in South Brazilian schoolchildren. Dent Traumatol. 2013 Aug;29(4):297-302. doi: 10.1111/edt.12003. Epub 2012 Oct 16.

19. Jorge KO, Moysés SJ, Ferreira EF, Ramos-Jorge ML, Zarzar PMA. Prevalence and factors associated to dental trauma in infants 1-3 years of age. Dent Traumatol. 2009 Apr;25(2):185-9. doi: 10.1111/j.1600-9657.2008.00730.x.

20. Andreasen JO, Ravn JJ. Epidemiology of traumatic dental injuries to primary and permanent teeth in a Danish population sample. Int J Oral Surg. 1972;1(5):235-9.

21. Skaare AB, Jacobsen I. Primary tooth injuries in Norwegian children (1-8 years). Dent Traumatol. 2005 Dec;21(6):315-9.

22. MestrinhoHD, Bezerra AC, CarvalhoJC. Traumatic dental injuries in Brazilian preschool children. Braz Dent J. 1998;9(2):101-4. 